\title{
A bankfelügyelés megújulása
}

\section{The Renewal of Banking Supervision}

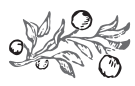

Összefoglalás

A pénzügyi felügyelés, ezen belül a bankfelügyelés az elmúlt száz év során folyamatosan fejlődött mind intézményrendszerét, mind módszertanát, szemléletét tekintve. A fejlődésre a legnagyobb hatással a különböző gazdasági válságok és egyes pénzügyi intézmények botrányai voltak. Ahhoz, hogy esélyünk legyen a pénzügyi válságok bankrendszerre gyakorolt hatását tompítani, illetve a bankoknál felmerülő problémákat idôben észlelni és megfelelóen kezelni, a pénzügyi intézmények felügyelésének folyamatos megújulására van szükség. A magyarországi felügyelés legújabb korszakának kezdetét 2013. október 1-jére tehetjük, amikor a Magyar Nemzeti Bank átvette a Pénzügyi Szervezetek Állami Felügyeletének feladatkörét, ezáltal a mikroprudenciális felügyelés integrálódott a magyar jegybankba. A megújulás tetten érhetố a magyar felügyelet teljes eszköztárában, ideértve a folyamatos felügyelést és a vizsgálati módszertanokat is. A megújulás elsôsorban szemléletmódváltást jelent, mely szerint a reaktív, azaz „utólag a kockázatokat kezelő” felügyelés helyett a proaktív szemléletre kell koncentrálni. A technológiai fejlődés révén a Felügyelet folyamatosan képes jelen lenni egy intézmény életében anélkül, hogy gátolná annak üzleti tevékenységét. Mindemellett a digitális csatornák rohamos terjedése robbanásszerúen megváltoztatta az emberek és az intézmények pénzügyi szokásait. Az informatika az élet egyre több területén nélkülözhetetlen, az ebben rejlő kockázatok kezelése, felügyelése komoly kihívást jelent, melyhez innovatív megoldások szükségesek. Az írás a legújabb felügyeleti fejlesztéseket és szabályozásokat mutatja be.

Journal of Economic Literature (JEL) kódok: G01, G21, G29, O30, O39

Kulcsszavak: megújult bankfelügyelés, innovációk a felügyelésben, MNB Felügyelet

Dr. KANDrÁcs Csaba, MNB pénzügyi szervezetek felügyeletéért felelôs ügyvezetô igazgató (kandracscs@mnb.hu). 


\section{Summary}

Financial supervision, and more specifically, banking supervision, has been continuously developing in the past one hundred years in terms of its institutional system, methodology and approach. The most significant impacts that triggered development included various economic crises and the scandals of certain financial institutions. In order to have the opportunity to mitigate the impact of financial crises on the banking system, and to notice the problems arising at banks in time and adequately manage them, supervision over financial institutions must be regularly renewed. The beginning of the most recent renewal of supervision in Hungary may be set at 1 October 2013, when the National Bank of Hungary took over the powers and competences of the Hungarian Financial Supervisory Authority and thus integrated micro-prudential supervision into the central bank of Hungary. Renewal is perceptible everywhere in the complete toolbox of Hungarian supervision, including the methodologies of continuous supervision and audit. Renewal primarily means a change in approach: instead of responsive supervision, i. e. "subsequent risk management", focus should be placed on a proactive approach. With the help of technological development, MNB as a supervisory body can be present in the life of institutions without preventing their business activity. In addition, the rapid spread of digital channels has changed the financial habits of people and institutions apace. Information technology is indispensable in an increasing number of areas in our lives, and the management and oversight of the risks involved is a major challenge that requires innovative solutions. In this study the most recent supervisory developments and regulations are presented.

Journal of Economic Literature (JEL) codes: G01, G21, G29, O30, O39

Keywords: renewed banking supervision, innovation in supervision, MNB as a supervisory body

\section{A NEMZETKÖZI BANKFELÜGYELÉS RÖVID ÁTTEKINTÉSE}

Általánosan elmondható, hogy a pénzügyi piacok felügyelésének fejlódése, így a bankfelügyelés fejlődése is kéz a kézben járt és jár a különbözô pénzügyi intézményi botrányokkal, bankválságokkal, egyes esetekben egész bankrendszereket érintô turbulenciákkal. Mind a pénzügyi felügyelést ellátó intézményrendszerben bekövetkezett változások, mind a felügyelés eszközrendszerében megjelenô újítások általában reakciót jelentenek a sajnálatos intézményi csődökre és az ebből fakadó megtakarítói vagy adófizetôi veszteségekre. Ezek a mérföldkövek jól azonosíthatóak: ilyen volt az 1929-1933-as gazdasági válság, amelyet követő́n egyes országokban jogszabályi szintre emelték a felügyeletet ellátó szervezetek szabályozását, ugyanakkor a fejlődés a nemzetállamok szintjén maradt meg, és napjaink legfejlettebb pénzügyi piacai voltak az élenjárók, mint az Egyesült Államok, Hollandia, Belgium. A nemzetközi szinten egységes szabályozási megközelítések érdemi elindulása is egy ismert bank, a Herstatt bankház válságához köthetô, mely eredményeként az 
1970-es években indult el a bankfelügyelés, bankszabályozás nemzetközi összefogása. A Bázeli Bankfelügyeleti Bizottság 1974 év végi létrehozása óriási lépés volt abba az irányba, hogy a szabályozás globális szinten egységes irányba induljon el: egységes megközelítések, elvek jöjjenek létre, mely a világ minden táján meghatározza a bankolás alapjait. Annak, hogy a bázeli bizottsági ajánlások hogyan váltak egyre komplexebbé, és hogyan jutottak el a tôkekövetelményeken át, a hitelkockázati előírásokon keresztül az egyéb kockázati szegmensekig, külön irodalma van. A 2008-as gazdasági válság volt a legutóbbi olyan nemzetközi esemény, mely számos bank megszúnését eredményezte szerte a világon, egész bankrendszerek, országok kerültek nehéz helyzetbe, és amely érdemi hatással volt a felügyeleti intézményrendszerre. Ezt követôen döntött úgy egyre több ország, hogy a bankfelügyelés feladatát a jegybankokba telepíti, ezzel is erôsítve annak függetlenségét.

Az intézményi, szabályozási, módszertani innovációk kiváltó oka tehát általában a pénzügyi intézményi válságok, nagyobb gazdasági válságok voltak, ugyanakkor a technológiai fejlődés is folyamatosan támogatja a felügyeletek fejlôdését. Ahogy más ágazatokban, itt is meghatározó szerepük van az informatikai újításoknak, hiszen ezek által lehetôség nyílik mélyebben, naprakészebben részt venni az intézmények mindennapjaiban, és szükség esetén megfelelő idôben beavatkozni. A folyamatos jelenlét, a problémák minél hamarabb történô felismerése és lehetôség szerint minél gyorsabb kezelése minden korban megjelenô igény volt, de a 21. század technológiai fejlődése kínál olyan megoldásokat, melyek segítségével ezek minden korábbi idôszaknál jobban megvalósíthatóak.

\section{BANKFELÜGYELÉS MAGYARORSZÁGON}

Magyarország, a magyar bankfelügyelés sem maradhatott ki a nemzetközi megatrendekből, még ha a fejlett pénzügyi piacokhoz képest időben később is kezdődtek meg a változások. Intézményi oldalról az 1989-90-es rendszerváltozás környékén jöttek létre a pénzügyi rendszer különbözô szektorait felügyelô entitások, kezdetben egymástól függetlenül. Ezt követôen az 1990-es évek második felétôl elkezdődött a pénzügyi szektor különbözố piacaihoz kapcsolódó felügyeletek fúziója. Elsôként a bankfelügyelet és a tôkepiaci felügyelet egybeolvadása történt meg, majd 2000-tôl kezdôdôen létrejött a Pénzügyi Szervezetek Állami Felügyelete, mely a biztosításfelügyeletet is magában foglalta. A 2008-as gazdasági válság, mint a világ számos más országában, hazánkban is rámutatott arra, hogy a kockázatok megfelelő időben történő feltárásához újfajta felügyelési stratégiára van szükség. Ugyanakkor a jegybanktól elkülönülő, integrált felügyeleti megközelítés egészen 2013-ig múködött. A megújuláshoz vezetô út mérföldköve 2013. október 1. volt, amikor a Pénzügyi Szervezetek Állami Felügyeletének megszúnésével a Magyar Nemzeti Bank feladatköre kiegészült a felügyeleti és fogyasztóvédelmi funkciókkal, ezáltal a makro- és mikroprudenciális mandátum egy intézményen belül összpontosulhatott. 2014 folyamán szintén a Magyar Nemzeti Bankban (MNB) alakult ki a szanálási szakterület, melyen keresztül a problémás és eredeti múködési formájában már nem fenntartható, rendszerszinten jelentôs intézmények hatékony válságkezelése valósulhat meg. Összességében tehát, az alapvetố nemzetközi trendekkel összhangban, a pénzügyi rendszer felügyeleti funkciója integrálódott a Magyar Nemzeti Bankba, lét- 
rehozva ezzel a világ egyik legkomplexebb eszközrendszerével rendelkezó jegybankját, mely egy intézménybe sû́ríti a pénzügyi rendszer valamennyi piacának, így a bank, biztosítás, pénztár, tốkepiac, közvetítôi piac mikroprudenciális felügyelését, a pénzügyi rendszer makroprudenciális felügyelését, a szanálás feladatát, valamint a pénzügyi fogyasztóvédelmet is, nem megfeledkezve a monetáris politika teljes eszköztáráról.

1. ábra: A Felügyelet története

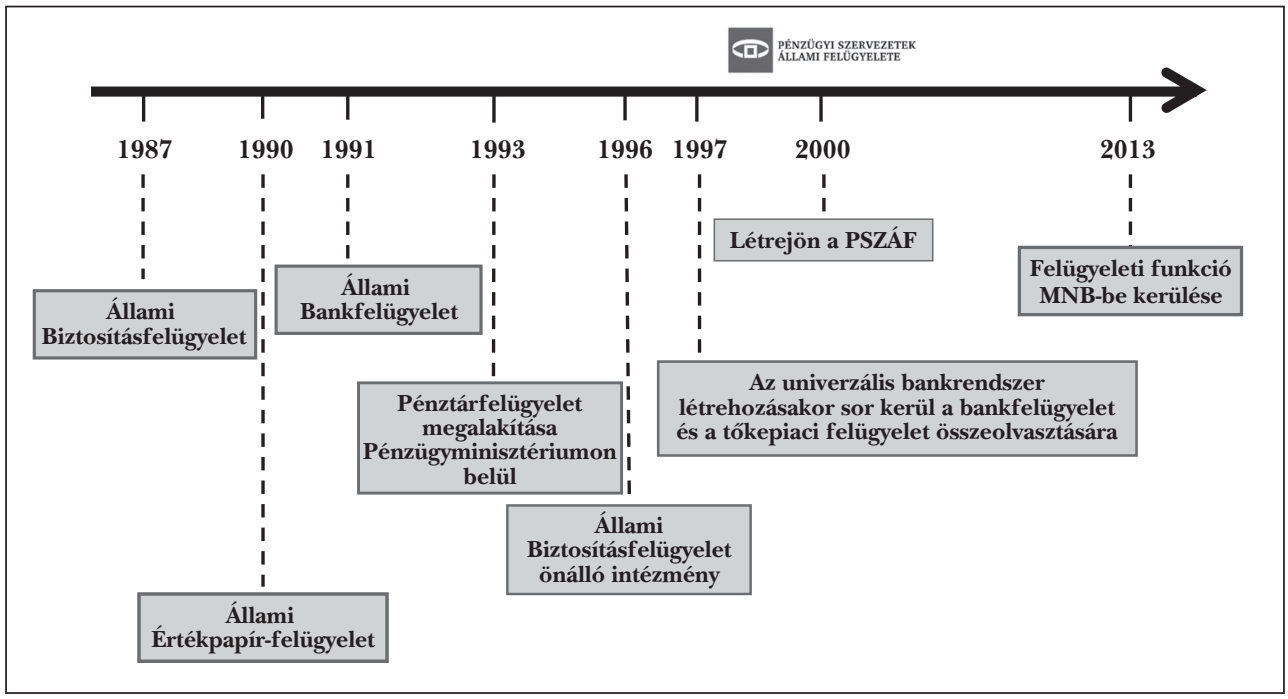

Forrás: $M N B$

A pénzügyi stabilitás fenntartását szolgáló eszközrendszerében megerôsödött MNB a 2013-as év második felétôl kezdődôen számos lépést tett annak érdekében, hogy új szemlélet és módszerek kidolgozásával képes legyen megfeleló módon és idóben hatékonyan kezelni a pénzügyi rendszert, ezen belül a bankrendszert érintố kockázatokat. A folyamatos fejlesztéseknek köszönhetôen a korábbi, idôszakonkénti ellenôrzési szemléletet - amely fóként a fennálló kockázatokat kezelte - felváltotta az előretekintô szemlélet, azaz a forward looking felügyelés, valamint a kockázatalapon szervezôdô, folyamatos, minél szorosabb jelenlét az intézmények életében. A 2008-as pénzügyi válság megmutatta, hogy a piac önszabályozó képessége csekély, ezért a felügyeleti szervekre hárul az a feladat, hogy az egészségtelen, a pénzügyi közvetítőrendszer múködését veszélyeztetô jeleket, gyakorlatokat azok széles körú elterjedése elôtt felismerje és megállítsa.

\section{A FOlyamatos FElügYelés MEGÚJUlása, ALAPMONITORING ÉS KORAI FIGYELMEZTETÓ RENDSZER}

A hatékony felügyeleti tevékenység alappillére az idóben történô beavatkozás képessége. A reaktív jelleg proaktívra történô módosításának elsố számú eszköze, hogy a felügyelés súlypontja az időszakos helyszíni vizsgálatokról egyre inkább a folyamatos felügyelés irá- 
nyába tolódik el. A technológiai eszközök támogatják ezt a folyamatot, és talán egy nap elérhetjük azt az állapotot, hogy fizikai jelenlét nélkül, automatikusan, a nap huszonnégy órájában online információval rendelkezzünk egy felügyelt hitelintézetrôl. Ennek egyik eloofeltétele ugyanakkor az, hogy a felügyeletek a korábbinál sokkal részletesebb információkkal rendelkezzenek a felügyelt intézmények múködéséról. Ennek jegyében hazánkban - az EU más országaihoz hasonlóan - megtöbbszöröződött az intézményektől bekért adatok mennyisége. Ez azonban önmagában még nem elegendó, hiszen a beérkezett adatokat fel is kell tudni dolgozni, a rengeteg információt szintetizálni szükséges, és ki kell nyerni belólük azokat az elemeket, melyek idóben feltárják, ha egy intézmény kockázatnak, ezen belül is kezelendô kockázatnak van kitéve. Ehhez szükség volt egy alap-monitoringrendszer fejlesztésére és az ezen alapuló korai figyelmeztetô rendszer kialakítására, amely a beérkezô adatokból kiindulva, több tucat mutatószám segítségével jelzi a problémákat. A jelzések feldolgozását követôen kiderül, hogy szükség van-e felügyeleti beavatkozásra. Ez az alap-monitoringrendszer, mely egyfajta folyamatos elórejelzố rendszernek tekinthetô, állandó módszertani fejlesztés alatt áll. Időról idôre újabb és újabb mutatószámok aktiválása történik a monitoring eszköztárban. Ennek oka az a felismerés, hogy egy bank múködését nem elegendő kockázati szegmensenként (hitelkockázat, múködési kockázat, piaci kockázat stb.) megragadni, érdemes vizsgálni azt is, hogy egy felíveló gazdasági környezetben, vagy éppen egy válságban, illetve a válságot követóen melyek azok az összefüggések, amelyek a legjobban megragadják egy bank jelenbeli helyzetét és a jövơben várható kockázatait. A 21. század technológiai fejlettsége kínálja a lehetôséget, hogy a monitoringrendszer minél inkább informatikai alapokon nyugodjon, és egyre inkább automatizált legyen, valamint, hogy a monitoringinformációkra egyfajta jelzörendszer is kiépülhessen. Az pedig, hogy a mesterséges intelligencia térnyerése milyen újfajta dimenziókat nyit meg az automatizálás, elôretekintố szemlélet terén, még csak most bontakozik ki előttünk. A jelzőrendszer lényege, hogy amennyiben a felügyelet számára érdekes és értékes adatokban hirtelen változás, nem várt elmozdulás, a korábbiaktól eltérô mintázat rajzolódik ki, a rendszer jelzést küld egy, az adatok értékeléséért felelős kolléga számára, aki ezt követôen megvizsgálja a jelzés okát, és ha szükséges, intézkedik a probléma elhárítása érdekében. 2013 óta számos új, komplex mutatószám vizsgálja és értékeli a különbözó kockázati szegmenseket annak érdekében, hogy minél hamarabb észlelhetô legyen, ha egy bank kockázatossága kedvezőtlen irányba mozdul el.

A rendszer azonban önmagában nem lenne képes betölteni a funkcióját, ha ezen számszaki információkat nem egészítenék ki kvalitatív információk, amelyeket a felügyelet egyrészt a rendszeresen megtartott prudenciális interjúk alapján, másrészt a rendszeres adatszolgáltatás fontos pillérét jelentő, legfőbb döntéshozó testületek üléseire kerülố anyagok bekérésén keresztül kap meg. A rendszeres intézményi interjúk, melyekre a rendszerszinten jelentôs intézmények esetében negyedévente kerül sor, kiváló alkalmat adnak arra, hogy a számokból ki nem olvasható információk, az üzleti modellt, stratégiát érintô változtatások feltáruljanak. A beszélgetések során az intézmények képviselôi reagálni tudnak a monitoringrendszerból kiolvasható trendekre, egyszeri kilengésekre, valamint a felügyeleti terület is meg tudja fogalmazni véleményét az intézmény múködéséről. 
A legfőbb döntéshozó testületek üléseire kerülô anyagok, mint például az igazgatósági, felügyelőbizottsági, legfóbb hitelezési bizottsági ülésekre készült elôterjesztések, jegyzókönyvek megismerése biztosítja a Felügyelet számára, hogy szorosan kövesse, érzékelje, milyen irányba mozdul el az adott intézmény. Természetesen egy bank a múködése során rengeteg döntést hoz, melyek feldolgozása komoly erőforrást igényel, és a Felügyelet kapacitása ezek teljes körú feldolgozására véges, de a technika fejlődése, valamint a kockázatalapú megközelítés támogatja, hogy a rendszerszinten jelentôs intézmények tevékenysége egyre alaposabban nyomon követhetô legyen. Szintén a korai beavatkozást segítik elő az intézményektől nagyobb mennyiségben és gyakorisággal begyújtött egyéb információk is, például testületi üléseken történô gyakoribb részvétel, továbbá a fogyasztóktól érkezô, a felügyelés folyamatába becsatornázott jelzések. Ezen adatok feldolgozásával az MNB munkatársai naprakészen nyomon követhetik az adott pénzügyi intézmény tevékenységét, múködését, és szükség esetén idejében be tudnak avatkozni a kockázatok, jogszabálysértések elhárítása érdekében.

Az előzőekben bemutatott alapvető információs források (monitoringrendszer, prudenciális interjúk, testületi üléseken való részvétel és azok anyagai, fogyasztói jelzések) rendszeres, negyedéves értékelése következtében a Felügyelet valóban képes az intézmények múködésének fóbb irányait előrejelezni, és felismerni az esetleges negatív tendenciákat. A gyakorlatban, a negyedéves értékelések keretében az adott intézmény említett információforrásainak feldolgozásáért felelős szakértő összefoglalót készít a vezetés számára, hogy az eltelt idôszakban, kockázati alapon melyek az említést érdemlô legfontosabb változások, események, továbbá amennyiben szükséges, további felügyeleti lépésekre tesz javaslatot. Kiemelendő, hogy a felügyelési tevékenység a korlátos erőforrások miatt kockázatalapon történik. Ennek lényege, hogy minden intézményt évente besorolnak a pénzügyi szektorra gyakorolt hatása alapján. Minél jelentôsebb egy intézmény múködésének hatása a hazai pénzügyi szektorban, illetve a gazdaságban, annál nagyobb hangsúlyt szükséges fektetni rá a felügyelése folyamán. A kockázatalapú felügyelés során az MNB az egyes intézményeket a pénzügyi rendszerben betöltött súlyuk és kockázati profiljuk alapján felügyeli és ellenôrzi.

\section{A VIZSGÁlati MÓDSZEREK, KÜLÖNÖS TEKINTETTEL A HELYSZÍNI VIZSGÁlATOK MEGÚJULÁSÁRA}

Az előzô rész bemutatta, hogy napjainkban a hazai pénzügyi felügyelet milyen eszközök segítségével, milyen információs csatornákon keresztül éri el a bankrendszer intézményi szereplőit, és kíséri figyelemmel azok tevékenységét annak érdekében, hogy naprakész információkkal rendelkezzen, jövőbe mutatóan tudjon következtetéseket levonni a bank múködését illetôen, és szükség esetén időben be tudjon avatkozni. Ezek azonban a helyszínen kívüli, úgynevezett folyamatos felügyelés kategóriájába tartoznak, melyek önmagukban nem elegendőek ahhoz, hogy átfogó képet kapjunk egy hitelintézetról. Ezeket egészítik ki a különbözó helyszíni vizsgálatok, melyek alkalmával a felügyeleti kollégák helyszínen tekintik át az adott intézmény múködésének 
egyes elemeit. Az MNB törvényi kötelezettsége, hogy meghatározott időnként átfogó helyszíni vizsgálatot folytasson a felügyelt intézményeknél.

A 2013 októberét követôen megújult felügyeleti múködésben tetten érhetô változás, hogy a Felügyelet elmozdult abba az irányba, hogy a jogszabályban meghatározott átfogó vizsgálati követelmény mellett egyre több egyéb vizsgálatot is lefolytasson a bankrendszer szereplőinél. Ezek a vizsgálatok - összhangban az MNB általános múködési szemléletével - sokkal inkább célzott, egy-egy problémára, kockázatra fókuszáló események. A szemléletbeli megújulás háttere, hogy napjaink gazdasági és szabályozói környezete által támasztott elvárások okán a felügyelt intézmények folyamatai és belsố kontrollrendszerei olyan gyorsan változnak, hogy szükségessé vált az intézmények kockázatainak ellenőrzése az átfogó vizsgálatok között is egy-egy adott témában. Egyszerúbben fogalmazva, túl gyorsan változik a pénzügyi világ ahhoz, hogy elegendô legyen 3-5 évente részletesen, helyszínen megvizsgálni az intézményeket. Ahhoz, hogy pontos képet kaphassunk egy intézmény mindennapjairól, fejlôdési irányairól, fokoznunk kellett a jelenlétet. Természetesen ez erőforrásigényes feladat, és a Felügyelet rendelkezésre álló kapacitásai is végesek, ugyanakkor a kockázatalapú vizsgálati tervezés segítségével az átfogó vizsgálatok közötti szúkebb fókuszú cél- és témavizsgálatok elôtérbe kerülésével komoly lépést tudtunk tenni a kitúzött célunk felé.

2. ábra: A felügyelés intézményi szemszögböl

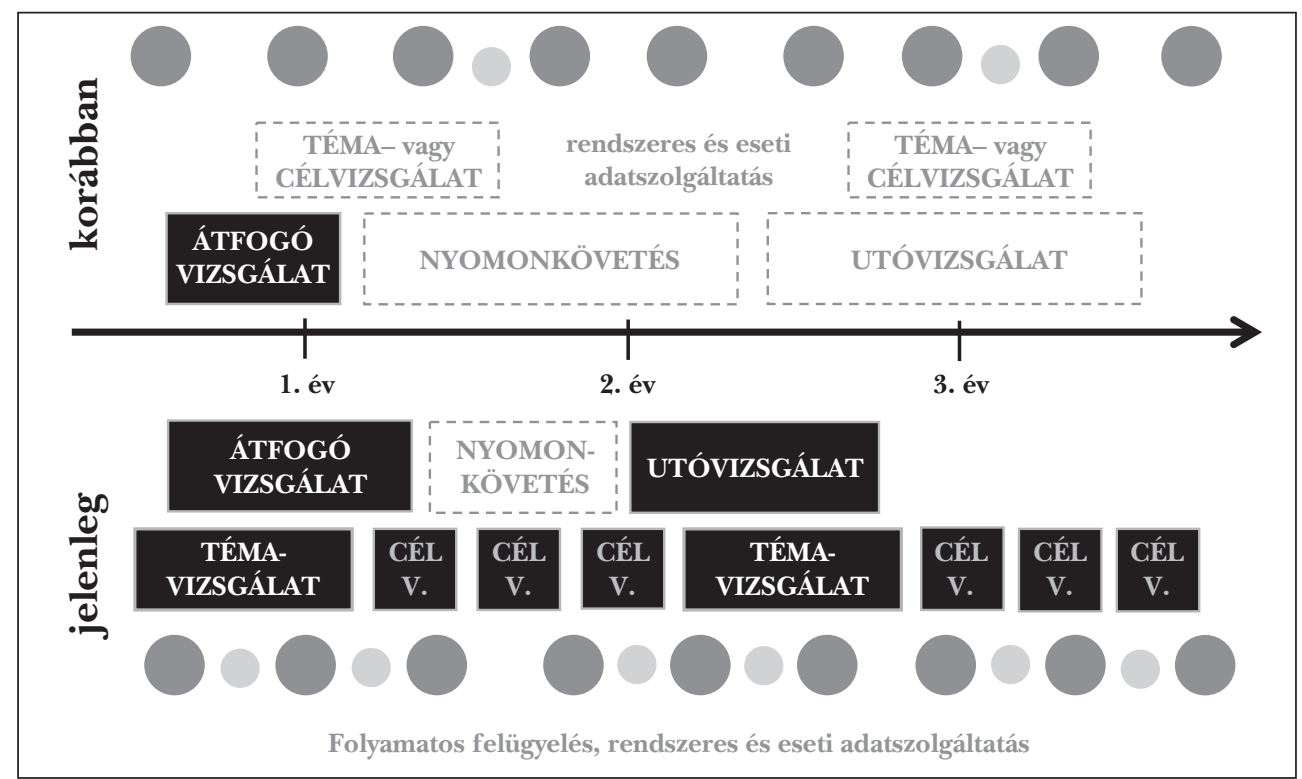

Forrás: $M N B$

Az új megközelítés elônye, hogy a kockázatok felmerülését követôen rövid idôn belül vizsgálni lehet azokat, és szükség esetén lehetôség van beavatkozni még a negatív események eszkalálódása elôtt, megelőzve így a kockázatok rendszerszintú felépü- 
lését. A témavizsgálatok eredményeként az MNB a vizsgált kockázat vonatkozásában szektorszintú, horizontális információbázissal és értékeléssel képes rendelkezni, ezzel is elôsegítve a minél egységesebb felügyeleti fellépést. A kockázatok azonosítására a folyamatos felügyelésból érkezô információk kiértékelése, valamint a felügyeleti adatszolgáltatások feldolgozása alapján kerül sor, azaz a folyamatos felügyelés érdemben támogatja és befolyásolja, hogy mikor, milyen típusú vizsgálatra kerüljön sor egy banknál a rendszeres, átfogó vizsgálat mellett.

A gyors és hatékony felügyeleti reakciók segítésére létrejöttek az úgynevezett operatív vizsgálati egységek, melyek kifejezetten a kockázatok gyors helyszíni vizsgálatára specializálódtak. Tevékenységük célja, hogy a folyamatos felügyelés során jelzett információkra, illetve kockázatokra alapozva azonnali helyszíni vizsgálatra, illetve beavatkozásra legyen lehetôség. Az operatív vizsgálatok esetében a különbség a többi vizsgálattal szemben, hogy a vizsgálat megkezdésérôl nem szükséges előzetesen értesíteni a vizsgált intézményt, valamint egy-egy meghatározott, konkrét témában történik a vizsgálat, mely során gyakran kerül sor az intézmény adathordozói (pl. számítógépek, telefon) tartalmának lemásolására (Lehmann et al., 2017).

A témavizsgálat eszközével élve az MNB 2015. év során tizenegy bank esetében vizsgálta, hogy javadalmazási gyakorlatuk megfelel-e a jogszabályoknak, és az nem ösztönzött-e túlzott kockázatok vállalására, továbbá, hogy a csoportvezetố bankok javadalmazási politikájukat érvényesítik-e az összevont alapú felügyelet alá tartozó csoporttagoknál. 2016. év során a lakossági nemteljesítố hitel (NPL) témavizsgálat keretében az MNB 11 intézmény gyakorlatának megismerése alapján kereste a választ arra, hogy a bankok rendelkeznek-e az NPL-állomány csökkentésére irányuló stratégiával, valamint a szükséges erőforrással és megfelelő eszköztárral. A szektorszintú kockázatok és piaci gyakorlat megismerésére a vizsgálatok mellett elótérbe került a különböző kockázatokhoz kapcsolódó témakörök mély, felmérésalapú elemzése. 2017-ben az intézmények értékvesztésképzési módszertanának, valamint a fedezetkezelési gyakorlatának elemzése történt meg, ez utóbbi közvetlen eredménye egy átfogó ingatlanértékelési felügyeleti ajánlás hatályba lépése 2018-ban. ${ }^{1}$

Természetesen az átfogó vizsgálatok sem vesztették el jelentôségüket az évek során, ugyanakkor több módszertani újítás következtében itt is erôsödött a célzottság, fókuszáltság. Az átfogó vizsgálatok megújítása keretében az alábbi módszertani változások erôsítették az elmúlt idôszakban az MNB fellépését a hitelintézeti szektorban:

- Az átfogó vizsgálatok programját illetôen erôsödött a kockázatalapú tervezés, így a folyamatos felügyelésből érkezô információk kiértékelése, valamint a felügyeleti adatszolgáltatások feldolgozása alapján kijelölt vizsgálati fókuszok hangsúlyosabb szerepet kapnak a vizsgálatok lefolytatása során. Ennek következtében az átfogó vizsgálatokon belül is vannak olyan kockázati szegmensek, melyek megvizsgálása mélyebben, részletesebben, egyes esetekben nagyobb mintán keresztül történik a nagyobb bizonyosság érdekében.

- Az éves felügyeleti prioritások kezelésének átfogó vizsgálatokban betöltött szerepe szintén nôtt az elmúlt években. Ennek elôzménye, hogy az MNB minden évben a következô felügyelési év tervezési idôszakának keretében értékeli az elôzó évi felügye- 
leti eseményeket, tapasztalatokat, valamint kitekint a várható gazdasági környezetre, jövôre vonatkozó trendekre, kockázatokra, és ez alapján átfogó felügyeleti prioritásokat határoz meg. Ilyen prioritások voltak például a válságot követôen keletkezett NPL-állományok leépítésének elôsegítése, a globális számviteli követelményekben bekövetkezó változások eredójeként bevezetett IFRS-sztenderdekre való átállás nyomon követése, valamint a hitelezés beindulásának eredményeként kialakuló új hitelezési folyamatok szoros nyomon követése. Ezek a horizontális prioritások jelennek meg hangsúlyosabban az átfogó vizsgálatok vizsgálati programjában.

- A korábbi ügyletátvilágítás-alapú, tisztán jogszabálymegfelelésre fókuszáló ellenórzési gyakorlatot egy többlépcsôs ellenôrzési metódus váltotta fel:

a) Annak érdekében, hogy a jogszabályi megfeleléseken túl az egyes prudenciális megfelelôségi ellenôrzések adott intézmény szintjén minél szélesebb körben valósulhassanak meg, az MNB az elmúlt idôszakban megteremtette annak keretrendszerét, hogy a jogszabályi és prudenciális követelmények teljesítését portfóliószinten, analitikus eszközök segítségével vizsgálja, amelyek a hitelintézetek által előállított magas granuláltságú vizsgálati analitikák felhasználásával valósulnak meg. Az intézmények által előállított, mély adattartalommal bíró hitel- és fedezeti analitikák azt követôen, hogy azok teljeskörúségét az MNB főkönyvi egyezőségen keresztül vizsgálta, egy több száz ellenórzést tartalmazó szúrési csomagon mennek keresztül, amelynek keretében többek között az alábbiak felülvizsgálata történik: a megadott adatmezók helyes formátumban való kitöltése; az intézmények értékkészleteinek és az MNB által elvárt értékeknek az ekvivalenciája; az egyes adatmezók közötti logikai kapcsolatok megfeleló alkalmazása; hitelfedezeti érték- és jövedelemarányos törlesztôrészlet-szabályok alkalmazása; ügyfél-, ügylet- és fedezet-felülvizsgálatok megfeleló időben történő elvégzése; az ügyfél- és ügyletminôsítési kategóriák helyes alkalmazása; fedezetallokáció megfelelôsége; szegmentáció helyes alkalmazása; csoportos értékvesztés szintjének megfelelôsége; a tôkekalkuláció során alkalmazott kockázati súlyok megfelelósége.

b) Az MNB folyamatszemléletben végzi az egyes kockázati folyamatok auditját, ezzel is elôsegítve a rendszerszintú hiányosságok feltárásának lehetôségét.

c) A fentiek alátámasztására, a gyakorlatban észlelhetố hiányok feltárására az MNB összetett módszertan alapján statisztikai, szakértôi és fókuszált mintavételt alkalmaz.

d) Az MNB a folyamati auditok során kiemelt figyelemmel vizsgálja a kockázatvállalási tevékenységek informatikai támogatottságát, szoros együttmúködésben az IT biztonsági felügyelést ellátó területekkel, ellenórzi a vonatkozó informatikai alkalmazások prudenciális megfelelését.

e) A vizsgálatok során, a feltárt hiányosságok mielóbbi orvoslása érdekében az MNB proaktív kommunikációt folytat, a múködésében tapasztalt hibák tényét több körben jelzi a vizsgált intézmények felé.

A megújult bankfelügyelés további fontos újítása - összhangban a nemzetközi követelményekkel - az intézmények likviditási helyzetének, illetve a likviditási kockázatok kezelésének ellenôrzésére szolgáló, ún. ILAAP-felülvizsgálatok, ${ }^{2}$ melyekre - a rendszeres adatszolgáltatásból nyert információk elemzése mellett - helyszíni vizsgálatok keretében kerül sor. Korábban az MNB a bankrendszer likviditásának figyelésére és a 
likviditáshoz kapcsolódó rendszerszintú kockázatok mérésére a mérleg- és betétfedezeti mutatókat alkalmazta, mely mutatókat a 2008-as pénzügyi világválság tapasztalatai alapján kivezettek. Ezeket felváltotta a nemzetközi szabályozási sztenderdek szerinti, a likviditást befolyásoló tételek szegmentáltabb, mélyebb elemzését lehetôvé tevô ún. likviditásfedezeti követelmény (Liquidity Coverage Ratio, LCR) mutató (Lehmann et al., 2017). „A hatályos jogszabályok által előírt likviditásfedezeti követelmény értelmében az intézményeknek olyan mennyiségú likvid eszközökkel kell rendelkezniük, amelyek értékének összege stresszhelyzetben fedezi a likviditási kiáramlások és beáramlások különbségét, ezzel biztosítva azt, hogy olyan szintú likviditási puffert tartsanak fenn, amely alkalmas lehet arra, hogy súlyos stresszhelyzetben harminc napig áthidalja a ki- és beáramlások közötti esetleges egyensúlyhiányt” (Lehmann-PalotaiVirág, 2017:883). Az LCR-mutató alkalmazásának gyakorlati tapasztalatai ugyanakkor a mutató bizonyos hiányosságaira is rámutattak, jelesül, hogy az nem veszi figyelembe a betétállomány koncentrációjából fakadó kockázatot, emiatt a felügyelet ebben a tekintetben is iránymutatást adott a szektornak a rendszeresen megújuló ICAAP/ILAAP kézikönyv módosításán keresztül. A módosítás lényege, hogy az intézményekkel szembeni elvárásként fogalmazódott meg, hogy a betétállomány egy bizonyos százalékát meghaladó egyedi betéteknek a küszöbérték feletti részének fedezése teljes mértékben likvid eszközökkel történjen. A likviditási kockázatok felügyelésének kiemelt területei dinamikusan változnak a bankrendszerre ható tényezook függvényében, így alkalmazkodva a banki gyakorlatokban rejló kockázatokhoz. Ilyen azonosított kockázat például a lekötött, de felmondható betétek figyelmen kívül hagyása az LCR-ben. Az MNB tehát elvárja, hogy az intézmény a forrásait ne automatikusan a lejárat alapján sorolja be az LCR-kategóriákba, hanem tekintse át, hogy azok nem rendelkeznek-e valamilyen lehívhatósági opcióval. Szintén a kockázatok alulbecsléséhez vezet az operatív kapcsolat nem megfelelô felmérése. Az LCR-számítás során a betétnek csak azt a részét kell operatív betétként kezelni, amely azon szolgáltatás igénybevételéhez szükséges, amelynek a betét a mellékterméke. Ennek megfelelóen az MNB elvárja, hogy az operatív betét kategóriát használó intézmény rendelkezzen módszertannal arról, hogyan határozza meg az operatív kapcsolat fenntartásához szükséges egyenleget. Másrészt végezzen statisztikai becslést, hogy az operatív és nem operatív részre osztott betétállomány átlagos kiáramlási faktora megfelelôen tükrözi a teljes betétállomány kockázatát. Az MNB ezen kiemelt témák nyilvánosságra hozatalával is segíti az intézményeket a jogszabályi követelmények pontos meghatározásában, a rájuk ható likviditási kockázatok azonosításában és kezelésében.

Szintén a nemzetközi elvárásoknak felel meg az MNB azáltal, hogy ICAAP-felülvizsgálatot $^{3}$ tart a bankoknál, mely vizsgálat a hitelintézetek által meghatározott, az általuk vállalt kockázatok fedezésére szolgáló tôkemértéket értékeli, és szükség esetén további tôkekövetelményt határoz meg az intézmény számára. Ennek kiindulási alapja, hogy valamennyi hitelintézet számára nemzetközi szabályokból eredô előírás a belsô tốkeszükségletének felmérése, valamint olyan számítási eljárások kialakítása, melyek segítségével az intézmény fel tudja mérni a szükséges tôkekövetelménye mértékét. Az európai felügyeleti hatóságok - így a magyar felügyelet is - elvárják, hogy az intézmé- 
nyek rendszeresen vizsgálják meg, a rendelkezésükre álló tôke stresszhelyzetben fedezi-e a felmerülố veszteségeiket. Ezek a vizsgálatok kockázati típusonként történnek meg, a legnagyobb súllyal a hitelezési kockázatok szerepelnek, amelyek a szerzôdéses partnerek fizetési kötelezettsége nemteljesítésének az intézmény jövedelmezôségére és tőkehelyzetét érintő veszteségekre vonatkozó kockázatát jelentik. Ennek keretében kerül sor a nemfizetés, a partner, a devizahitelezés, az elszámolási, a részvényjellegú kitettségek, a koncentrációs, az ország- és a reziduális kockázatok értékelésére. A hitelkockázatok mellett mint kockázati típus kiemelt vizsgálat tárgya a múködési jellegú, a piaci, a banki könyvi kamat, az üzleti és stratégiai jellegú, illetve a szabályozói környezetből adódó kockázat. Az MNB évente értékeli a hitelintézetek kockázati típusonként magukra számított tôkekövetelményét. Ennek módszertana folyamatos fejlôdésen ment keresztül az elmúlt öt évben, melyre hatással voltak a válság tapasztalatai. Korábban a rendszerszinten nem jelentôs, gyenge hatással rendelkezó intézmények ICAAP-felülvizsgálata évente desktop alapon történt, helyszíni vizsgálat nélkül, ugyanakkor a rendszerszinten jelentős intézmények mindegyikére évente helyszíni vizsgálattal egybekötött értékelésre került sor. Az elmúlt évek során a jegybanknak kialakult egy transzparens és markáns véleménye mind a kockázatok kezeléséról, mind a kockázatokat fedezô tôkekövetelmények számításáról. Ez utóbbi kapcsán benchmark módszertanok kidolgozása történt, amely a kockázati modellek tekintetében az intézmények által használt számos különbözô számítási módszer elfogadhatóságát vagy elvetését alátámasztja. Ez biztosítja a transzparenciát az intézményekkel szemben, másfelól segítséget is nyújt a matematikai és statisztikai alapokon nyugvó modellek összehasonlításában is. Összefoglalva tehát, az intézmények méretének és kockázatosságának függvénye volt az ICAAP-felülvizsgálat módszertana. Tekintettel arra azonban, hogy a rendszerszinten jelentôs hitelintézetek az évek során megértették, megtanulták az ICAAP-számítással kapcsolatos MNB-elvárásokat és módszertant, és az éves felülvizsgálatok során egyértelmúvé vált, hogy az ICAAP-számítások beépültek az intézmények mindennapjaiba, lehetôség nyílt arra, hogy elmozdulás történjen abba az irányba, hogy minden intézményt helyszíni vizsgálat keretében is értékeljenek. Természetesen a rendelkezésre álló, korlátozott kapacitások miatt ezek csak bizonyos idôközönként valósulhatnak meg. Szintén érv volt a változtatás mellett, hogy az ügyfél, betétes, hitelezô oldaláról nincs olyan, hogy kicsi vagy nagy bank, rendszerszinten jelentôs vagy kevésbé jelentôs intézmény, egy betétes azzal a tudattal bízza rá a forrását egy bankra, hogy biztonsággal vissza is kapja azt, és a Felügyelet feladata, hogy ez a fajta közbizalom minden intézmény irányában meglegyen. Az új megközelítés lényegileg abból áll, hogy az intézmények három kategóriába kerülnek besorolásra méretük és kockázatosságuk függvényében. Az elsố kategóriába tartozó intézmények átfogó, teljes ICAAP-felülvizsgálatban vesznek részt, a második csoportba sorolt hitelintézetek szúkített fókuszú, célzott vizsgálat alanyai, de a helyszínen is megjelenik a Felügyelet, míg a harmadik kategóriába tartozó intézmények esetében helyszíni vizsgálat nélküli értékelésre kerül sor. A módszertan alapján háromévente minden intézmény átesik egy átfogó felülvizsgálaton, de a rendszerszinten legjelentôsebb, valamint a legkockázatosabb intézményeket továbbra is helyszíni vizsgálat keretében értékelik a felelős felügyelők. 
Polgári Szemle $\cdot 15$. évfolyam 1-3. szám

Adatmentési, adatelemzési támogatás a helyszini vizsgálatok során

A folyamatos felügyelés részeként elvégzett adatelemzéseken túl az MNB az általa lefolytatott helyszíni vizsgálatok, eljárások részeként is végez adatgyújtést és elemzést. Ez a típusú adatgyújtés két csoportba sorolható be az információ feldolgozásának szempontjából: amikor az eljárásban szükséges adatok leválogatását a felügyelt intézmény hajtja végre, illetve amikor a leválogatás az MNB által, az MNB telephelyén történik, a teljeskörûség biztosítása és ellenôrzése érdekében. „Az adatgyújtés legmagasabb szintje, amikor az MNB a vizsgált intézmény vagy annak munkatársa tulajdonában álló adathordozóról - ideértve valamely tárhelyszolgáltató által tárolt adatokat is - fizikai tükörmásolatot vagy hiteles másolatot készít, és ennek felhasználásával a mentett adatokat átvizsgálja. Ebben az esetben nemcsak az adatok helyreállítása és feldolgozása az MNB felelôssége, hanem az adatok sértetlenségének, hitelességének bizonyítása is, amelyet jelenleg az MNB ún. hashkód, hasítófüggvények felhasználásával biztosít. Az adatbázismentések feldolgozása során elsố lépésben a lementett adatbázis platformjával megegyezó informatikai környezet kialakítása a feladat, majd az adatbázis a felügyelt intézmény telephelyén elérhetôvel azonos módon történő helyreállítása történik. Ezután kerül sor - logikájában az adatbekéréssel megegyezó - szúrések, kimutatások, elemzések elkészítésére. A viszszaállított adatbázisból történó adatlekérdezéseknek számos előnye van az adatbekéréssel szemben. Egyrészt jelentôsen alacsonyabb az adathamisítás kockázata; az ellenôrizhetôség teljes körú; lehetôség van pontosabb kockázati besorolás alapján történô mintavételre a mélyebb vizsgálatokhoz, másrészt kiküszöbölhetôk az adatbekérố és az adatszolgáltató közötti információs aszimmetriából adódó problémák (például az adatszolgáltató nem az elvárt logikával/tartalommal készíti el a kimutatást). Az adatbázismentésnek azonban speciális követelményei is vannak, például magasabb szintú IT-infrastruktúra szükséges, magasabb az információs biztonsági kockázat, fokozott humánerőforrás-igénye van, és a Felügyeletnek szélesebb körú információval és szaktudással kell rendelkeznie a vizsgált intézmények egyedi múködésének tekintetében. A fizikai tükörmásolat vagy hiteles másolat feldolgozása annyiban tér el az adatbázismentések feldolgozásától, hogy ebben az esetben a másolat tartalma ismeretlen a feldolgozás kezdetéig a Felügyelet számára, továbbá a másolat tartalma strukturálatlan, ezért az MNB-nek rendelkeznie kell a megfelelő adatelemzési infrastruktúrával és az ehhez szükséges szaktudással” (Lehmann-Palotai-Virág, 2017:876-877). Az MNB ugyanakkor a rendszeres adatszolgáltatás tekintetében is elmozdult a granuláris adatok gyújtése felé, mivel ezek bázisán sokkal részletesebb és pontosabb elemzések végezhetôk mind a Felügyelet, mind pedig az MNB más területei által. Ennek a megkezdett útnak jelentôs mérföldköve lesz egy olyan MNB által kezdeményezett projekt 2020-ban való indulása, amely gyakorlatilag a felügyelt intézmények teljes hitelportfóliójáról ad rendszeres, elemi információkat az MNB részére, kiváltva ezzel a nagyszámú, jelenleg aggregát adatokat tartalmazó adatszolgáltatási táblát. 


\section{Felügyeleti stresszteszt}

Már volt arról szó, hogy az MNB szemlélete szerint a pénzügyi szektor stabilitásának biztosításához nagyban hozzájárul az elôretekintô (forward looking) szemlélet. Ennek egyik eszközének tekinthetố a stressztesztek alkalmazása. Ezen terheléses vizsgálatok azt hivatottak ellenórizni, hogy egy jelentôs mértékú makrogazdasági sokk bekövetkezése mellett a felügyelt hitelintézetek kellóen likvidek és tôkeerôsek maradnának-e. A legutóbbi pénzügyi válság kitörése óta különös figyelem övezi a bankok sokkellenálló és veszteségelnyelô képességét. Ennek vizsgálatát a nemzeti mikroprudenciális hatóságok segítségével 2009 óta végzi az Európai Bankhatóság (EBA) a nagyobb európai bankcsoportokra, azonban e teszteknek mind ez idáig nem volt materiális következménye. A közös európai bankfelügyelet egyik legnagyobb vívmánya az egységes átfogó felügyeleti felülvizsgálati és értékelési eljárás harmonizációja és ajánlásba foglalása volt, mely alapján a felügyeletek egységesen végzik a bankok kockázatainak feltárását. Annak érdekében, hogy az egyes országokban múködő, külföldi anyabankkal rendelkező, valamint a hazai tulajdonú pénzügyi intézmények stresszellenálló képessége közvetlenül, a nemzeti felügyeletek által is vizsgálható legyen, az EBA kiegészítette az említett ajánlását, melyet 2018. július 19-én publikált. ${ }^{4}$ A 2019. január 1-jétôl hivatalosan hatályba lépett iránymutatásban a hitelintézetekre, illetve hitelintézeti csoportokra számított Pillér II-es tôkeajánlás (röviden: Capital Guidance vagy P2G) megállapítását várja el az érintett hatóságoktól. Ezzel a 2017 óta formálódó, pénzügyi rendszer és külön-külön a bankok stabilitására, biztonságosabb múködésére irányuló újítás is beépült a szabályozásba. Ennek meghatározásához felügyeleti szolvenciastressztesztek kialakítására volt szükség, melynek az MNB 2018 elején eleget is tett. A mikroprudenciális hatóság az elsô évben a komplex SREP alá tartozó, mérlegfőösszeg alapján a legnagyobb magyar székhelyú bankokra, majd 2019-tôl a kis- és közepes bankokra is lefuttatja az említett, általa fejlesztett stressztesztet, és meghatározza a Capital Guidance-t. A P2G olyan felügyeleti iránymutatás, mellyel a mikroprudenciális hatóság meghatározza, hogy mennyi tôkepuffert tart indokoltnak az elôírt SREP-tókekövetelményen (TSCR) és makroprudenciális tókepuffereken (együttesen OCR) felül ahhoz, hogy a felügyelt intézmény stresszkörülmények között se sértse meg a rá vonatkozó tôkekövetelményt. Ez tehát egyfajta „megfelelő követési távolság”. A bankok menedzsmentje eddig is tartott plusztôkét, hogy elkerülje a tôkekövetelmény-sértést, a továbbiakban azonban ezt a felügyelet számszerúsíti egy egységes stresszteszt keretében, és előírja a bankoknak ajánlás formájában. Fontos kiemelni, hogy az új eszköz iránymutatás, és nem minôsül direkt tôkekövetelménynek, az csupán a felügyelő hatóság által kívánatosnak tartott, a stresszteszt eredményei alapján indokolt többlettóke mértékét határozza meg. A felügyelet a tôkesértést (kvázi karambolt) szankcionálja szigorúan, a „megfelelố követési távolság” tartását csak kívánatosként szabja meg. Az MNB ugyanakkor szorosabban nyomon követi azon intézményeket, ahol azt tapasztalja, hogy e puffer nem elegendó, és esetlegesen a tervezési horizonton tôkesértésre van kilátás, azaz a Felügyelet által meghatározott megfelelô követési távolságon belül 
van az intézmény. Az adott évben érvényben lévő P2G alapesetben a megelőzó évben lefolytatott stresszteszt alapján kerül megállapításra. A 2019. január 1-jétól érvényben lévő egyedi banki (szubkonszolidált) szinten meghatározott P2G-értékeket így a 2018-ban folytatott stressztesztek eredményeképp kalkulálja az MNB. Mivel a P2G-t csak ajánlás szintjén fogalmazták meg, így a megállapított érték megsértése eleinte csupán intenzív, a felügyelet és az adott bank közti kommunikációt, illetve tôkehelyzet-helyreállítási terv elkészítését vonja maga után. Az együttmúködési szándék hiányában azonban a felügyelet akár a tôkesértés esetére fenntartott eszközöket is alkalmazhatja.

A felügyeleti stresszteszt módszertani alapját az EBA által kifejlesztett európai szintú párja adja. Ahhoz azonban, hogy a tesztelés a magyar pénzügyi szektor minden résztvevôjére teljes mértékben használható legyen, a nagyobb európai bankcsoportokra általánosított keretrendszert kissé át kellett dolgozni. A legfóbb módszertani különbség a részleges bottom-up, vagyis bizonyos meghatározott keretek közé szorított banki belsố modellek használatán alapuló megközelítésrôl való áttérés volt. A magyar felügyelet által fejlesztett stresszteszt, a bankok közti jobb összehasonlíthatóság kedvéért, teljes mértékben központosított, azaz mind a makroszcenárió meghatározása, mind az előrejelzéshez felhasznált modellek és az adatokkal való feltöltés is az MNB kezében összpontosul. A bankszabályozás célja a forward looking szemlélet továbberôsítése, melyhez hozzájárult a hitelintézetek által használandó számviteli sztenderd megváltoztatása is. Az európai hitelintézetek számára a 2018-tól bevezetett IFRS9 egyik legfóbb újítása a hitelek értékvesztésképzését érintette. Míg az előzô értékvesztési modell csak a ténylegesen, bizonyítékokkal alátámasztottan felmerült veszteségeket tudta kezelni, addig az új sztenderd a várható hitelezési veszteségeket modellezi, mely idóben elôrébb hozza az értékvesztésképzést. Ehhez az irányhoz csatlakozott 2019-tôl a felügyeleti stresszteszt is, mely így megfelelôen és realisztikusabban tudja modellezni a dinamikában és mértékben is máshogy jelentkezô értékvesztésképzéseket egy esetlegesen bekövetkezô válság, romló makrogazdasági környezet szimulálása esetén.

\section{Életképességi értékelés a folyamatos felügyelés és a vizsgálatok bázisán}

Az előző fejezetekben bemutattuk, hogy a felügyeleti tevékenység gerincét jelentő folyamatos felügyelés, valamint a különbözô helyszíni vizsgálatok milyen tevékenységeket ölelnek fel. Ezek azonban nem pontszerú események sorozata, hanem a belőlük kinyert információk egy komplex, intézményi éves értékelésben csúcsosodnak ki. Ez annak a koncepciónak a leképezódése, mely szerint a felügyelés egy megszakítatlan folyamatot jelent. Ezen folyamat adott évre vonatkozó záróakkordja $a z$ életképességi vagy SREP-dialógus, amely rendszerbe foglalja az adott évben a felügyelet által megvalósított minden tevékenységet, a rendszeres adatszolgáltatások feldolgozásától az elvégzett vizsgálatokon keresztül a prudenciális interjúkon át az adott évi helyszíni vizsgálatokig, ILAAP-, ICAAP-értékelésekig. A 2017-es év végétôl az Európai Bankfelügyelet által kidolgozott módszertanra épüló rendszer több mint 70 mu- 
tatószám és kvalitatív információk elemzése alapján mond egyértelmú véleményt az intézmények életképességérôl, múködésük fố aspektusairól, mint a vállalatirányítás, hitelkockázat, múködési kockázat, tôkehelyzet és likviditás, transzparens és összehasonlítható elvek mentén történő értékelése útján. A felügyelés egész rendszerét átfogó SREP-dialógus adott évre vonatkozó összefoglalását jelentő SREP CEO-megbeszélések tematikája azért erre az értékelésre épült, mivel a mutatószett összetételén keresztül teljes áttekintést ad az intézmény múködésérôl és annak felügyeleti megítélésérôl. A rendszerszinten jelentôs intézmények tekintetében a mutatók negyedévente frissülnek, de a kisebb intézmények vonatkozásában is évente elkészül az elemzés és az ennek alapján elóálló értékelés. Az éves értékeló beszélgetések az intézmények legfelsôbb vezetői szintjén történnek meg amiatt, hogy a hitelintézet elsố számú vezetôje évente legalább egyszer lássa, hallja, mit gondol a Felügyelet az általa vezetett intézményrôl, melyek annak gyenge pontjai, fejlesztendô területei, legnagyobb kockázatai, valamint a következô év felügyelési fókuszpontjai. Itt megismerhetốk azok a folyamatos felügyelés keretében beérkezett információk, valamint helyszíni és egyéb vizsgálatok, melyek megalapozták az adott intézmény adott évi életképességi értékét. Ez a fajta logikailag zárt rendszerbe foglalt megközelítés az utóbbi évek felügyeleti vívmányai közé tartozik, mely segít, hogy a Felügyelet komplex módon átlássa és értékelje a bankokat, valamint, hogy a hitelintézetek értsék, tudják, mit hogyan kell tenniük annak érdekében, hogy a Felügyelet által legkockázatosabbnak ítélt területek fejlődjenek.

3. ábra: Kockázati és életképességi értékelés

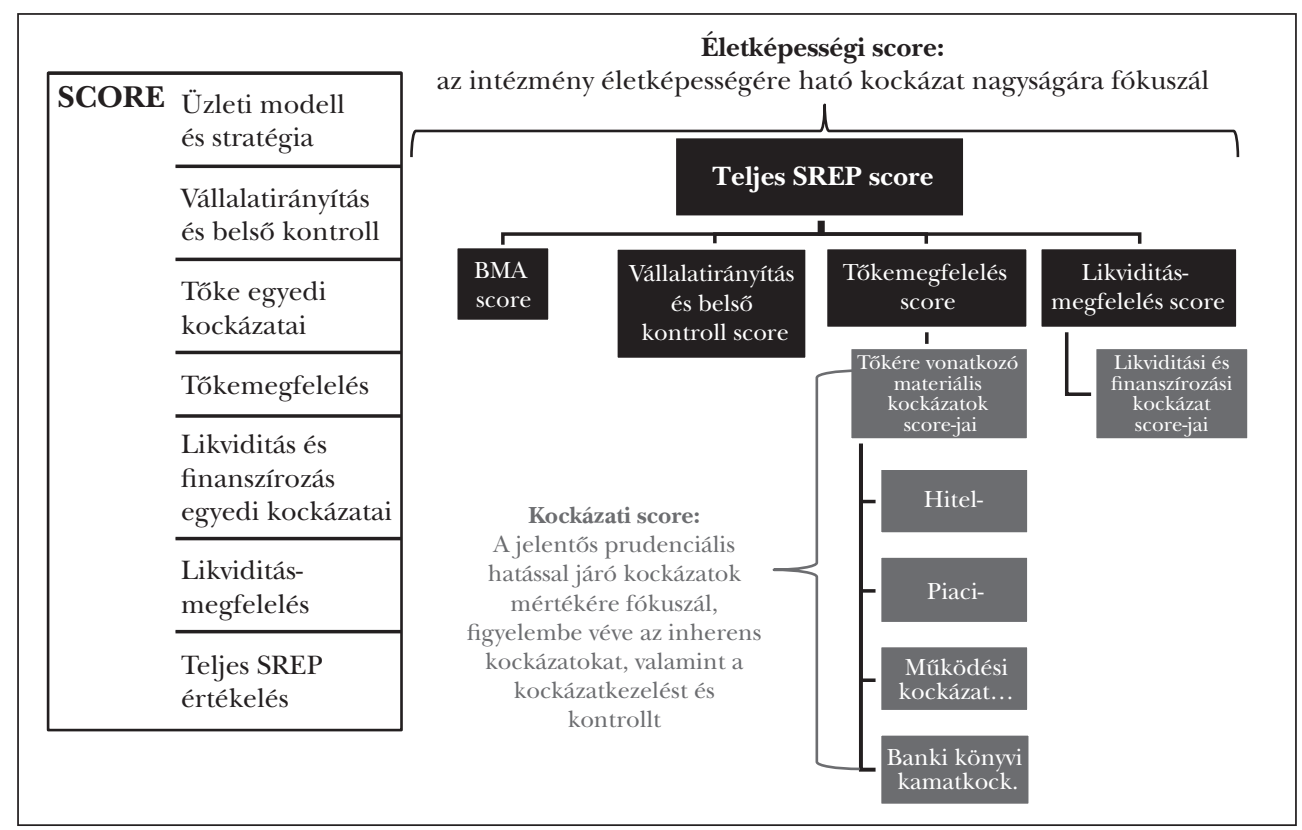

Forrás: $M N B$ 


\section{Polgári Szemle $\cdot$ 15. évfolyam 1-3. szám}

\section{SZABÁLYOZÁSI TEVÉKENYSÉG}

A mindenkori felügyelet kiemelt felelőssége, hogy a folyamatos felügyelés, valamint a vizsgálatok útján a szektorról szerzett információit vissza is csatornázza az intézmények felé jogszabályok, ajánlások és vezetôi körlevelek formájában, annak érdekében, hogy az intézmények gyakorlata minél teljesebb mértékben megfeleljen a prudenciális és egyéb elvárásoknak. A Felügyelet széles körben fogalmazott meg ajánlásokat a szektor felé az elmúlt idôszakban, amelyek egyik kulcsmotívuma volt a válságból és a válság utáni idôszakból leszúrhetô tapasztalatok kommunikálása a felügyelt intézmények felé. Bár hasonló eszköze az MNB-be kerülố felügyelési feladatot megelôzóen is volt a korábbi pénzügyi felügyeléssel foglalkozó intézménynek, tekintettel a korábban már említett MNB-s komplex pénzügyi stabilitási eszközrendszerre, a megjelenô ajánlások jobban figyelemmel lehetnek nemcsak a mikrofelügyelés keretében felmerüló problémákra, de a makroszintú kockázatokra is. Ebben a tekintetben kiemelt jelentôségú ezen ajánlások sorában a 2018 júliusában hatályba lépett NPL (non-performing loan) ajánláscsomag. Az ajánláscsomag több egymásra épülő ajánlás koherens rendszere, a válságban és a válság után tapasztalt rossz gyakorlatok megelőzését szolgálja, tehát az alapvetô cél, hogy a magas nemteljesítô hitelállományok kontrollálatlan módon ne is alakulhassanak ki a szektorban, és az intézmények folyamatosan készen álljanak a felépült rossz hitelállományok leépítésére, azok ne tokosodjanak be az intézmények könyveibe, mivel ezen állományok jelentôs eróforrásokat vonnak el az alaptevékenységtôl, rontva ezzel a pénzügyi közvetítőrendszer hatékonyságát. A csomag központi eleme az Európai Központi Bank NPL-ajánlásának implementációját megvalósító 10/2018 (II.27.) számú MNB-ajánlás, amely előírja, hogy a magas nemteljesítô hitelállománnyal rendelkező, felügyelt intézményeknek az NPL-állomány leépítésére vonatkozó stratégiával kell rendelkezniük, amelyet be kell nyújtaniuk a felügyeletnek. A stratégia elkészítése mellett az ajánlás szervezeti és folyamati elvárásokat is megfogalmaz annak érdekében, hogy a stratégiában megfogalmazott reális, de ambiciózus célok megvalósíthatósága biztosított legyen.

A csomag másik pillére az ingatlanalapú projektfinanszírozási ügyletek strukturálására, monitoringjára és a nemteljesítôvé váló ilyen ügyletek helyes értékelésére vonatkozó 12/2018 (II.27.) számú ajánlás. Az ingatlanalapú projektfinanszírozás jelentette a hazai bankszektor legnagyobb problémáját a válság idején, és emiatt kulcsfontosságú, hogy a válság tapasztalataiból levonható következtetések beépüljenek mind az intézmények, mind pedig a felügyelet gyakorlatába, amelynek praktikus megvalósulását jelenti az ajánlás.

A fentiekhez szorosan kapcsolódik a 11/2018 (II.27.) számú ajánlás, amely az ingatlanfedezetek értékelésére vonatkozóan ad praktikus iránymutatást, mind a felügyelt intézményeknek, mind pedig az ingatlanértékelôi szakmának, rögzítve olyan sarokpontokat mind az ingatlanértékelések szakmai tartalmával, mind pedig az ingatlanértékelések és az értékbecslôk banki kezelésével kapcsolatban, amelyek helyes alkalmazása esetén elérhetô, hogy az intézmények által fedezetbe vett ingatlanok figyelembevétele megfelelő értékkel történjen a hitelezési döntések során. 
Kandrács Csaba: A bankfelügyelés megújulása

\section{A FELÜGYELÉS DIGITÁliS MEGÚJíTÁSÁNAK GÉLJA ÉS ESZKÖZEI}

A korábbi fejezetekbôl kiolvasható újfajta szemléletbeli megközelítés, hogy az MNB mint Felügyelet törekszik az intézmények életében folyamatosan jelen lenni, anélkül hogy gátolná, lassítaná, ellehetetlenítené azok prudens üzleti múködését. A mai modern, informatizált világban ez a fajta megközelítés múködóképes tud lenni, de ehhez tovább kell fejleszteni a módszertanokat, alakítani a felügyelés eszközrendszerét. A kulcsszó a digitalizáció. Az MNB stratégiai célja és küldetésének meghatározó eleme a „digitális felügyelés” megvalósítása. A digitális felügyelés a gyakorlatban azt jelenti, hogy a Felügyelet folyamatosan keresi és implementálja azon technikai megoldásokat, újdonságokat, amelyek hatékonyabbá tehetik a tevékenységét. Egy felügyeleti megoldást egyrészt akkor tekintünk hatékonynak, amennyiben a felügyelés alapvetôen reaktív, utólagos jellegét proaktívra tudja változtatni, amely nem a már meglévô kockázatok kezelésére, hanem a kockázatok kiépülésének megakadályozására koncentrál. Másrészt, ha a véletlenszerú vagy szakértôi mintaválasztással múködô felügyelést sikerül leváltani egy, az adatok teljes körú vagy a lehetô legszélesebb körú feldolgozását magában foglaló kockázati alapú megoldásra. Harmadrészt, ha a feldolgozandó adatok begyújtése és feldolgozása minél nyersebb, hitelesebb formában történik, így csökkentve a csalás és az adatmanipuláció lehetôségét. Negyedrészt, ha a folyamatok automatizálása által a humánerőforrás-igényt vagy emberi hibák számát csökkenti.

\section{Informatikai felügyelet - csak a változás állandó}

Az informatikai felügyelet szintén azon területek közé tartozik, melyek állandóan változnak, ezáltal folyamatos szakmai fejlődést igényelnek ahhoz, hogy a szakértôk lépést tudjanak tartani a legújabb technológiákkal. Ugyanakkor az IT-felügyelés módszertani alapjait is szükséges idôrôl idôre megújítani, és proaktívan elébe menni a változásoknak. Mindeközben pedig olyan állandó, kiszámítható szabályozói környezetet kell biztosítani a felügyelt intézmények számára, mely lehetôvé teszi a technikai innovációt, és biztos keretet ad az új fejlesztések megvalósításához, hiszen egy nagyobb rendszercsere vagy új rendszer bevezetése általában többéves projekt. Ebben a szakmai kihívásokkal teli környezetben dolgozik a Magyar Nemzeti Bank informatikai felügyeleti szakterülete. A következőkben az informatikáról mint felügyeleti szakterületről lesz szó, ugyanakkor egyértelmúnek látszik az az irány, hogy modern felügyeletrôl nem lehet beszélni úgy, hogy ne válna minden nagyobb felügyeleti szakterület (folyamatos felügyelet, vizsgálati szakterület) egyre inkább informatikai szakterületté. Ma már olyan informatikai megoldások jelentek meg, amelyek rengeteg folyamatot tudnak automatizálni, és a mesterséges intelligencia soha nem látott lehetôségeket adhat a prudens banküzem folyamatos figyelemmel kíséréséhez. 
Az informatikai eszközök elterjedése, az okostelefonok térhódítása és a „digitális bennszülöttek” generációinak megjelenése azt eredményezte, hogy mostanra az informatika mindennapjaink részévé vált, és pénzügyeinket is egyre többször intézzük elektronikus csatornákon. Ezt az irányt a pénzintézetek és a szabályozók is felismerték, ezért a banki digitalizáció is egyre nagyobb hangsúlyt kap az intézmények stratégiai tervei közt. Ennek egyik terjedôben lévô példája a papír nélküli, esetenként az ügyfél fizikai jelenlétét sem igénylő szerződéskötés vagy jognyilatkozat-tétel. Emellett a pénzintézetek másik gyakori digitalizációs célja a pénzmosás-megelôzési szabályoknak megfelelô, távoli ügyfélazonosítás megvalósítása, mely a távoli számlanyitáshoz vagy hitelfelvételhez szükséges. Ezek a megoldások az elérhetô csúcstechnológia alkalmazását kívánják, miközben a háttérben múködô jelenkori informatikai rendszerek sokszor évek óta változatlan formában, több évtizedes rendszerlogika szerint üzemelnek. Ez a kettôsség mindennapi kihívást jelent - nemcsak a pénzintézetek, hanem az informatikai felügyelet számára is, mivel objektíven, a kockázatokra fókuszálva kell vizsgálnia nagyon eltérô, szemléletben és technológiában is külön világokat képviselô rendszereket, fejlesztési módszereket - akár egy cégen belül is. Ez a gyakorlatban a követelményrendszer és vizsgálati módszertan folyamatos újragondolását jelenti: minden egyes új technológia felveti azt a kérdést, hogy relevánsak-e még a korábban elvárt kontrollintézkedések, vagy van-e már valami jobb és korszerúbb kockázatcsökkentési intézkedés, amit a Felügyelet elvárhat vagy javasolhat. Alkalmazható-e ugyanaz az elvárásrendszer az agilis szoftverfejlesztésre, mint a hagyományos vízesés modellben készüloo alkalmazásokra? A válasz sok más tényezôtôl is függ (például a fejlesztốcsapat méretétôl, a szoftver rendeltetésétôl stb.), ezért a felügyelés során olyan rugalmas módszertani megközelítésre van szükség, melyet a szakértôk az adott helyzet pontos ismeretében, a körülményeknek megfelelően tudnak alkalmazni.

A technikai megoldások és fejlesztési, üzemeltetési módszertanok mellett maga az informatikai ellenôrzési elvárásrendszer is változik. Például már nem okvetlenül számít biztonságosnak az a jelszópolitika, amit tíz éve még bármely auditor megfelelônek értékelt. Ma már a jelszavas belépést önmagában nem tekintjük erôs azonosításnak, függetlenül attól, milyen jelszókomplexitási követelményeket állított be a rendszergazda. Ugyanígy változnak az elvárt kontrollintézkedések az informatika más területein is, bár a megvalósítandó kontrollcélok (például a felhasználó megfeleló azonosítása) ugyanazok maradnak. Épp ezért a felügyeleti módszertanok fejlődése is állandó, az egész vizsgálati keretrendszerre kiterjed, és a mélyebb technológiai vizsgálatok során használt útmutatók folyamatos naprakészen tartását is igényli.

Az MNB saját informatikai felügyeleti módszertanának állandó fejlesztése mellett egyre hangsúlyosabban megjelenó feladat a nemzetközi szabályozási trendek és irányok megismerése, követése, vagy akár proaktív részvétel ezek kialakításában. Az interneten keresztül nyújtott pénzügyi szolgáltatások sokszor országhatároktól függetlenül 
elérhetôek, ezért a hazai pénzintézetek és fintech cégek szempontjából fontos, hogy ne kerüljenek versenyhátrányba az esetlegesen szigorúbb szabályozási háttér miatt. Ugyanakkor arra is ügyelnie kell a Felügyeletnek, nehogy a túl laza szabályozás hibájába essen, ezáltal túl nagy kockázatnak tegye ki az ügyfeleket, vagy lehetôséget nyisson a pénzmosásra. Különösen igaz ez az informatikai felügyelés területén, mivel a pénzügyi technológiai innováció elsôsorban ezen a területen jelentkezik, és az ilyen újítások a Felügyeleten belül kerülnek górcsố alá az engedélyezési eljárások során, illetve a felügyelt intézmények vizsgálatánál. A nemzetközi szabályozó munkában való részvétel másik fontos mozgatórugója az egységes szemléletre és szabályrendszerre való törekvés. Világszerte fokozódó figyelem övezi a kiberbiztonsági incidenseket, és számos nemzetközi szervezet érzi úgy, hogy szabályozásokat kell alkotnia az általános kiberbiztonsági színvonal növelése érdekében. Ennek a szabályozói tendenciának azonban az a veszélye, hogy egymásnak ellentmondó, a gyakorlatban megvalósíthatatlan szabályozások születnek, amelyek összességében nemhogy javítanák, de éppenséggel rontják a pénzügyi rendszer kiberbiztonsági ellenálló képességét. Ezért is fontos, hogy az MNB-hez hasonló integrált, több szektorra jó rálátással rendelkezô felügyeletek fokozottan részt vegyenek a nemzetközi szabályozási és módszertani munkában, megosszák tapasztalataikat, és keressék a szinergiákat a meglévô és kialakulóban lévő szabályozási keretrendszerek közt.

Új eszközök az informatikai felügyelésben

Hagyományosan az informatikai felügyelet a helyszíni ellenôrzések alatt, különösen az átfogó vizsgálatok informatikai részvizsgálatakor, vagy a témavizsgálatok és célvizsgálatok során találkozik a felügyelt intézményekkel. Emellett az engedélyezési eljárások és állásfoglalás-kérések során is kaphatnak az intézmények informatikai vonatkozású szakvéleményt, melynek elkészítésében az informatikai felügyelet is közremúködik, de ilyenkor általában nincs közvetlen kapcsolat az intézmények informatikai vezetôi, szakértôi és az informatikai felügyelôk közt. Az elmúlt két évben az MNB törekedett arra, hogy a korábbiaknál közvetlenebb kapcsolatot alakítson ki a felügyelt intézményekkel. Az informatikai felügyelet szakértôi számos alkalommal biztosítottak konzultációs lehetôséget akár a Felügyelet által készített vizsgálati jelentésekkel kapcsolatban, akár tervezett nagyobb volumenú fejlesztések, rendszercserék, adatközpont-költöztetések során. A kiemelt informatikai projektek kapcsán a folyamatos felügyelet keretében az MNB jó gyakorlatnak tartja, ha az intézmények rendszeresen beszámolnak a projekt előrehaladásáról. Az ilyen személyes egyeztetések során a Felügyelet munkatársai válaszolnak az esetleg felmerülő kérdésekre, hogy ezzel is segítsék az intézmények megfelelését a jogszabályi és felügyeleti elvárásoknak. Az interaktívabb felügyeleti kapcsolattartás részeként az MNB igyekszik tapasztalatával is segíteni és nyomon követni a fôbb rendszercseréket, adatközpont-költözéseket, a teljes informatikát érintô kiszervezéseket vagy az intézmények egyesülésével, összevonásával járó rendszer- és adatmigrációkat. Ugyanakkor a Felügyelet törekszik arra is, hogy az ilyen nagy figyelmet és sok erôforrást igénylố projektek nyomon követése során szükségtelenül ne vonjon el erô- 
forrásokat a tényleges célok teljesítésétôl azzal, hogy esetleg többletkötelezettségeket (adatkérések, jelentések, helyszíni interjúk) ró az intézményekre. Ezért a felügyelôk igyekeznek olyan szinten megismerni a folyamatban lévó projektet, hogy fel tudják dolgozni az intézmény saját döntéshozói részére készült tájékoztató, döntéselókészítô anyagokat.

Az adatmigrációk vizsgálata során a hagyományos, mintavételezéses kontrolltesztelés továbbfejlesztése mellett az informatikai felügyelet alkalmaz a teljes adatpopuláció vizsgálatán alapuló eljárásokat is, megfelelố audit/adatelemzó szoftver támogatásával. Így a felügyeleti ellenórzések a korábbinál nagyon bizonyosságot szerezhetnek arról, hogy megfelelôen, adatvesztés vagy nem megfelelô módosítás nélkül történt-e az adatmigráció. Az adatok helyessége abból a szempontból is fontos, hogy a személyes adatok kezelése során az adatalany erre vonatkozó jogai nem sérülhetnek.

\section{A felhök felügyelete}

Az informatikában a „felhơ” olyan megoldás, amely lehetôvé teszi az igény szerinti hozzáférést a megosztott, konfigurálható számítástechnikai erőforrásokhoz, melyeket gyorsan lehet allokálni, és használatukat lezárni, minimális menedzsmentráfordítással vagy szolgáltatói közremúködéssel. Ily módon a felhő használatával viszonylag gyorsan lehet új - üzleti vagy informatikai - szolgáltatásokat megvalósítani, akár cégen belüli IT-fejlesztési kapacitás nélkül is. Rugalmassága miatt egyre több pénzintézet választ felhôs megoldásokat akár cégen vagy cégcsoporton belül (privát vagy közösségi felhô), akár kívül (publikus felhő). A felhô használata azonban mindig valamiféle kontrollvesztéssel jár az informatikai környezet felett, ha pedig a cégen belüli informatika teljes mellôzésével történik - hiszen erre is van lehetôség -, akkor akár az is előfordulhat, hogy még a rendelkezésre álló vagy könnyen megvalósítható kontrollintézkedések sem valósulnak meg. A választott felhôszolgáltatási modelltól függốen a teljes infrastruktúrát (Infrastructure as a Service, IaaS), a platformot (Platform as a Service, PaaS) vagy csak a szoftvert (Software as a Service, SaaS) veszi igénybe a felhôszolgáltató ügyfele, a felügyelt intézmény. A modell meghatározza, milyen szinten tartja a saját kezében az adatokat, hozzáféréseket, szolgáltatásokat a felügyelt intézmény, és menynyiben hagyatkozik a felhôszolgáltató saját megoldásaira. Mikor a felügyelt intézmények belevágnak egy új, valamelyik felhőalapú szolgáltatási modellre épüló megoldás kialakításába, olyan technikai és megfelelési kérdésekkel szembesülnek, melyek a hagyományos, fizikailag egy szerverre telepített IT-megoldások kiépítése és üzemeltetése során nem merülnek fel. Például a felhốk virtualizált világában könnyen elófordulhat, hogy az adat fizikai helyét még kontinensszinten sem tudja behatárolni az adat tulajdonosa. Az ilyen helyzetek elkerülése érdekében az MNB a korábban bemutatott szabályozási eszközéhez folyamodott, és ajánlást ${ }^{5}$ adott ki a pénzügyi szervezetek számára azzal a céllal, hogy gyakorlati segítséget nyújtson a közösségi és publikus felhőszolgáltatások igénybevételéből eredô kockázatok kezelésére és a vonatkozó jogszabályi rendelkezések alkalmazásának egységes értelmezéséhez. Az ajánlás útmutatást ad a jogszabályi előírások betartásához, meghatározza a szerződések elvárt minimumkö- 
vetelményeit, ismerteti a kezelendô kockázatokat, az elvárt kontrollintézkedéseket, a felügyeleti hatóság ellenôrzéseinek fố szempontjait, és illeszkedik más európai szabályozásokhoz. A felhôszolgáltatásokról szóló ajánlás ${ }^{6}$ legfrissebb, átdolgozott verzióját 2019 márciusában adta ki az MNB.

\section{SzABÁlyOZÓ ÉS A FINTEGH INNOVÁCIÓK}

Közkeletû mondás, hogy a fejlődés megállíthatatlan. Ez különösen igaz a 21. század elejére. A technológiai fejlôdés ez idáig soha nem látott sebességet ért el. Az átlagember számára is szinte minden újdonság viszonylag könnyen elérhetô. Az információs csatornák - internet, Facebook, Twitter, Tumblr és megannyi más - csak ontják magukból a híreket a világról.

Az információáradatban sok esetben igen nehéz kiigazodni, valamint a releváns, bennünket érdekló és hasznos információkat nem könnyú megszerezni, viszont a sok esetben szidott információözönnek van néhány jótékony hatása is: a fogyasztók - szolgáltatói szemüvegen keresztül nézve: ügyfelek - számára szinte azonnal elérhetôvé válnak azok az újdonságok, amelyek gyorsabb, kényelmesebb, nagyobb hozzáadott értéket tartalmazó és nem utolsósorban olcsóbb szolgáltatásokat, megoldásokat jelentenek. Illetve az ügyféloldalt tekintve, a fogyasztók oldaláról is az egyes szolgáltatásokkal szemben támasztott követelmények szinte azonnal megjelenhetnek a másik oldal számára is. A virtuális térben a keresleti és kínálati oldal így majdhogynem azonnal tud reagálni egyrészt a fogyasztói igényekre, másrészt pedig az újdonságok adta lehetôségekre. Természetesen ahhoz, hogy egy ötletból/igényből „termék” váljon, nem elegendô az információk megosztása, mindkét oldalon értő fülekre, a megvalósítás szándékára, valamint olyan szabályozói környezetre, látásmódra, eszközrendszerre van szükség, amely egyik oldalon támogatja az újdonságok piaci környezetbe történố implementálását, a másik oldalon pedig a piaci szereplôk részére garantálja az új termékekkel, szolgáltatásokkal megjelenô kockázatok miatt a piaci szereplók biztonságát. A szabályozó, felügyeletek által múködtetett - jelen ismereteink szerint legmodernebb - két támogató eszköz az „Innovation Hub”, valamint a „Regulatory Sandbox".

\section{Innovation $\mathrm{Hub}$}

A pénzügyi szabályozók a világ számos országában felismerték, hogy - más iparágakhoz hasonlóan - az innovációk piacra lépésének támogatása, szabályozása nélkül a szolgáltatások tekintetében lemaradnak a versenyben, valamint az országspecifikus gazdasági célok megvalósítása is veszélybe kerülhet. Az innovációt támogató szabályozói eszközök egyik eleme az ún. Innovation Hub. Az Innovation Hub a legtöbb esetben egy elektronikus felület, amely lehetôséget biztosít a szabályozó és a piaci szereplők, illetve a piaci szereplók egymás közötti közvetlen információcserére. Az Innovation Hubok múködésére nincsen általánosan elfogadott séma, országonként más és más lehet a múködési mechanizmus, viszont találhatunk megegyezó elemeket. 
Az MNB által múködtetett Innovation Hub a nemzetközi jó gyakorlatokat összesíti, könnyen kezelhetô felhasználói felülettel rendelkezô weboldal, amely az alábbi funkciókat tartalmazza:

- Információs tárházként múködik, azaz az egyes fejlesztésekre vonatkozó pontos jogszabályi környezetet mutatja meg a vonatkozó MNB-s elvárások feltüntetésével. Információkat tartalmaz az egyes engedélyek megszerzésére vonatkozóan.

- Ezen a felületen lehet a szabályozó felé feltenni az innovációs megoldáshoz tartozó, jogszabályban nem vagy nem teljesen szabályozott kérdéseket.

- Kommunikációs Hub, valamint nemzetközi kooperációs platform, ahol információk oszthatóak meg a piaci szereplôk között.

A szereplôk közötti információáramlás segítése mellett a felület fó funkciója a jogszabályi megfelelés biztosításához a szabályozói támogatás kérése. Értelemszerúen a platform csak előre meghatározott feltételek mellett múködtethetố hatékonyan. A kérdés benyújtását szerkesztett - könnyen értelmezhetó és kitölthetô - elektronikus úrlapon teheti meg a kérelmezô.

Regulatory Sandbox (Innovációs Pénzügyi Tesztkörnyezet, IPT)

A modern szabályozói eszköztár másik eleme a Regulatory Sandbox biztosítása, mely nem egyedi, kizárólag Magyarországon múködó eszköz, ez a megoldás már számos országban megtalálható. Ugyanakkor Európában az Egyesült Királyság után másodikként, régiónkban pedig elsóként került bevezetésre a szabályozott keretek között múködő Regulatory Sandbox 2018 decemberében.

A Sandbox alatt szabályozott piaci tesztkörnyezetet értünk pénzügyi termékek és szolgáltatások vonatkozásában, amely alkalmas arra, hogy az innovációkat meghatározott időkorlát betartásával, meghatározott ügyfélkörön a szolgáltatás/termék nyújtója kipróbálhassa oly módon, hogy a tesztidôszak alatt elôre meghatározott jogszabályi követelmények alól felmentést kaphasson. Az Innovációs Pénzügyi Tesztkörnyezet (IPT) célja, hogy a piaci szereplôk részére a túlzott kockázatvállalást megelôzze, illetve a tesztidôszak során felmerült tapasztalatok függvényében - amennyiben szükséges a vonatkozó jogszabályi környezetet módosítani lehessen. Ahogy az Innovation Hub esetében is a hatékony múködés elôsegítése érdekében a szabályozó oldal meghatározza a befogadási kritériumokat, az IPT tekintetében is definiálták az új termékekre/ szolgáltatásokra vonatkozó befogadási feltételeket:

- A terméknek/szolgáltatásnak innovatívnak kell lennie;

- A terméket/szolgáltatást a sikeres tesztidőszakot követôen a magyarországi piacon be kell vezetni;

- Az IPT-ben tesztelendô terméknek/szolgáltatásnak tesztelésre kész készültségi szinten kell lennie.

A szabályozó a tesztidőszakot megelőzóen egyeztet a szolgáltatóval, valamint az IPT-be történô belépési nyilatkozatot követôen a tesztidôszak végéig folyamatosan nyomon kíséri a tesztelési eredményeket. A tesztelés kimenetele háromféleképpen alakulhat: 


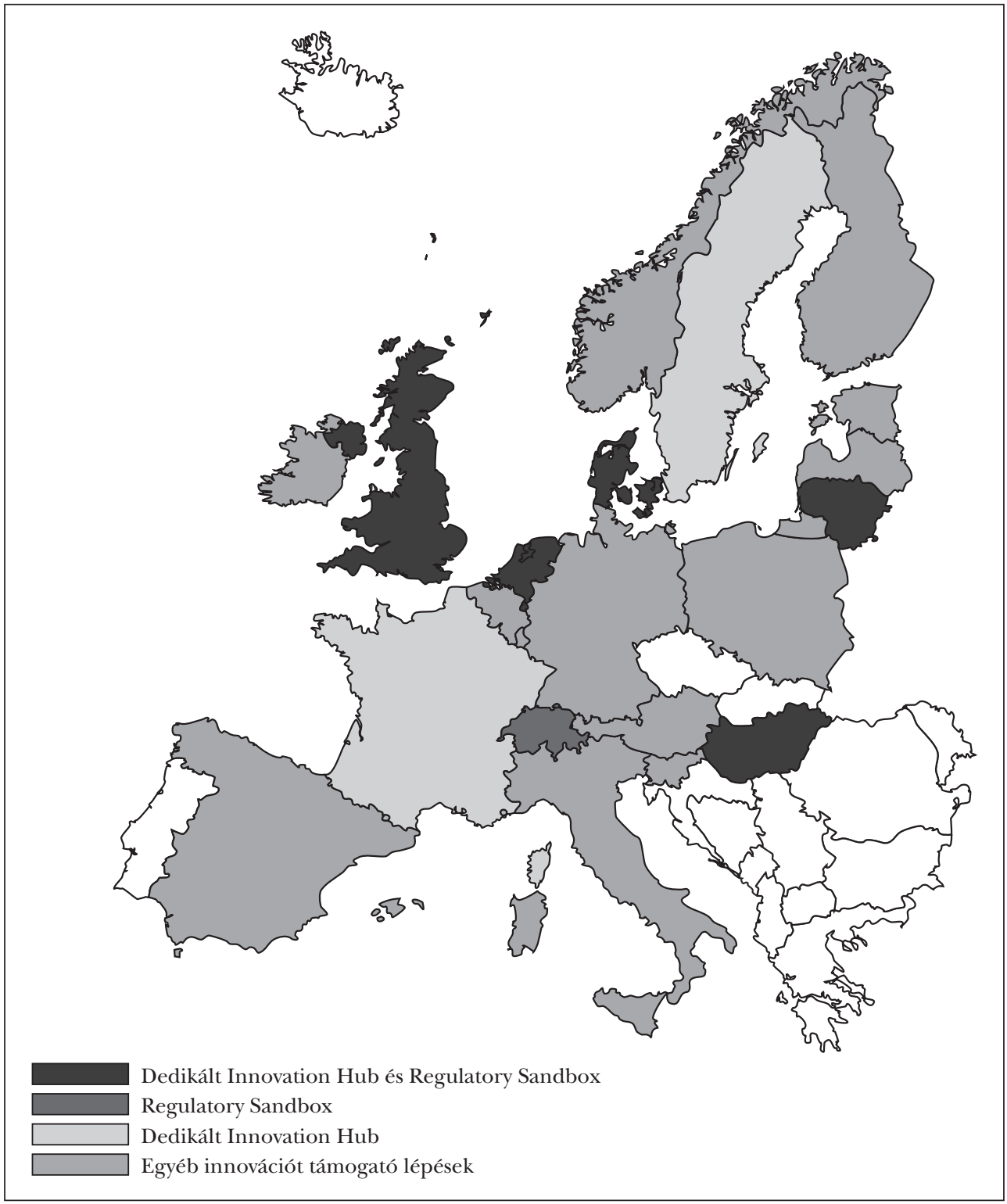

Forrás: MNB; EBA, https://eba.europa.eu/-/esas-publish-joint-report-on-regulatory-sandboxes-and-innovation-hubs

- A termék/szolgáltatás megfelel a jelenlegi szabályozói környezetnek, így a piacra teljeskörúen bevezethetô.

- A termék/szolgáltatás kapcsán a vonatkozó MNB-rendelet vagy -rendeletek módosítását követôen válik elérhetôvé korlátozások nélkül. 
- A szolgáltatás nem felel meg a jogszabályi környezetnek, valamint a jogszabályok nem módosíthatóak, így a szolgáltatás/termék nem nyújtható.

Az Innovation Hub és Regulatory Sandbox eszközökkel lehetôség nyílik arra, hogy a gyorsan változó világunkban a szabályozó rövidítse a pénzügyi fejlesztések piaci bevezetésének idôigényét, fenntartva a piaci szereplók részére - különösen ebben a szektorban kiemelkedô jelentôséggel bíró - elengedhetetlen biztonságot, valamint hogy a késóbbi Felügyelés könnyebb legyen azáltal, hogy az érintett hatóságok idôben megismerik, megértik az innovációk természetét, új felügyelési módszerekkel tudják támogatni azok múködését, és így minden felhasználó biztonságos keretek között tudja használni a különbözố pénzügyi újításokat.

\section{JEGYZETEK}

1 A Magyar Nemzeti Bank 12/2018. (II.27.) számú ajánlása az ingatlanfinanszírozási projekthitelek értékelésérôl és kezelésének egyes kérdéseirôl.

2 ILAAP - internal liquidity adequacy assessment process.

3 ICAAP - internal capital adequacy assessment process.

4 https://eba.europa.eu/documents/10180/2282666/Revised+Guidelines+on+SREP+\%28EBA-GL2018-03\%29.pdf

5 A Magyar Nemzeti Bank 2/2017. (I.12.) számú ajánlása a közösségi és publikus felhôszolgáltatások igénybevételérôl - 2019. május 1. napjával hatályon kívül helyezve, lásd 4/2019. ajánlást.

6 A Magyar Nemzeti Bank 4/2019. (IV.1.) számú ajánlása a közösségi és publikus felhôszolgáltatások igénybevételérôl.

\section{FELHASZNÁLT IRODALOM}

EBA (2018): Final Report. Guidelines on the Revised Srep and Supervisory Stress Testing (pénzügyi intézmények stresszellenálló képessége, SREP). https://eba.europa.eu/documents/10180/2282666/Revised+Guidelines+on+SREP+\%28EBA-GL-2018-03\%29.pdf.

Fábián Gergely - Virág Barnabás (2018): Bankok a történelemben: innovációk és válságok. Magyar Nemzeti Bank Könyvsorozata, Magyar Nemzeti Bank, Budapest.

ICAAP-ILAAP-BMA - Felügyeleti felülvizsgálatok. www.mnb.hu/felugyelet/szabalyozas/felugyeleti-szabalyozo-eszkozok/modszertani-kezikonyvek/icaap-ilaap-bma-felugyeleti-felulvizsgalatok.

Lehmann Kristóf - Palotai Dániel - Virág Barnabás (2017): A magyar út - célzott jegybanki politika. Magyar Nemzeti Bank Könyvsorozata, Magyar Nemzeti Bank, Budapest.

MNB (2019): Jelentés 2013-2019. Magyar Nemzeti Bank, Budapest, www.mnb.hu/letoltes/mnb-jelente-s2013-2019-hun-0220.pdf.

Szabó András Viktor (2018): Új tôkeajánlás vár a bankokra 2019-tôl. Világgazdaság, www.vg.hu/vilaggazdasag/vilaggazdasag-penzugy/uj-tokeajanlas-var-a-bankokra-2019-tol-1145639/. 